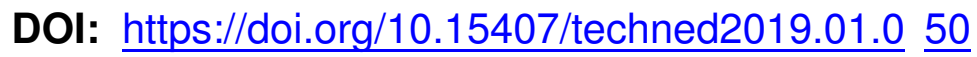

\title{
DETERMINATION OF SEAT OF A SINGLE-PHASE CIRCUIT TO EARTH UNDER CONDITIONS OF ELECTROMAGNETIC INFLUENCE ON THE AIR LINE OF SIGNALING, CENTRALIZATION AND BLOCKING OF RAILWAYS
}

$\quad$ Journal
Publisher
ISSN
Issue
Pages

\author{
Tekhnichna elektrodynamika \\ Institute of Electrodynamics National Academy of Science of Ukraine \\ 1607-7970 (print), 2218-1903 (online) \\ No 1, 2019 (January/February) \\ $50-54$
}

\footnotetext{
Authors

M.F. Sopel ${ }^{1}$, N.V. Grebchenko ${ }^{2 *}$, V.F. Maximchuk ${ }^{3}$, Y.V. Pylypenko ${ }^{4}$

1 - PE "ANIGER",

Harmatna str., 2, Kyiv, 03680, Ukraine

2 - National University of Life and Environmental Sciences of Ukraine,

Heroyiv Oborony st., 15, Kyiv, 03041, Ukraine,

e-mail: grebchenko@nubip.edu.ua

3 - Ukrzaliznytsia,

Tverska str., 5, MSP Kyiv-150, 03680, Ukraine

4 - Institute of Electrodynamics National Academy of Sciences of Ukraine,

pr. Peremohy, 56, Kyiv, 03057, Ukraine

* ORCID ID : http://orcid.org/0000-0003-0055-9042
}

\section{Abstract}

The analysis of the influence factors on the accuracy of the location of the earth fault on an 
overhead line with a distributed load The existence of an inverse dependence of the value of the first harmonic part in the voltage of the damaged phase from the distance to the closure is theoretically substantiated and experimentally confirmed. One of the main reasons for this is the distributed along the line load, which is connected to the line through single-phase transformers. Proposed measures to improve the quality of the electric energy of the line and the accuracy of the determination of the location of the closure. References 9, figures 5.

Key words: ground fault, higher harmonics, method, accuracy, experiment, modeling.

Received: 05.03 .2018

Accepted: 10.08 .2018

Published: 10.01 .2019

\section{References}

1. Baran P.M., Kydyba V.P., Ravlyk O.M. Determining the type and location of the damage on the lines with a branch. Elektroenerhetychni ta elektromekhanichni systemy. 2008. No 615. Pp. 8-13. (Ukr)

2. Shalit G.M. Determination of fault locations in electrical networks. Moskva: Energoatomizdat. 1982. 312 p. (Rus)

3. Mironov O.S., Djachenko M.D., Burlaka V.V., Bublik S.K. Method for determining the distance to a single-phase earth fault or isolation defect in isolated and compensated neutral electric networks. Patent Ukrainy No 94145. 2010. (Ukr)

4. Figurnov E.P., Bodrov P.A. Determination of the place of single-phase ground fault in the high voltage power lines of automatic block system of railways. Protection and automation of power systems 2004 2004. Pp. 88-93. (Rus)

5. German L.A., Veksler M.I., Shelom I.A. Equipment and lines of power supply for automatic 
lockout. Moskva: Transport, 1987. 192 p. (Rus)

6. Hamed Jafari Kaleybar, Hossein Madadi Kojabadi, Morris Brenna, Federica Foiadelli, Seyed Saeed Fazel. An active railway power quality compensator for $2 \times 25 \mathrm{kV}$ high-speed railway lines. 2017 IEEE International Conference on Environment and Electrical Engineering and 2017 IEEE Industrial and Commercial Power Systems Europe (EEEIC / I\&CPS Europe). Milan, Italy. Pp. 1-6.

7. Stognii B.S., Grebchenko N.V., Maximchuk V.F. Monitoring sestem for state of 10(6) kV signalization and blocking lines on railway. Tekhnichna Elektrodynamika. 2016. No 1. Pp. 40-46. (Ukr)

8. Zeveke G.V., Ionkin P.A., Netushil A.V., Strachov S.V. Fundamentals of the theory of chains. Moskva: Energo-atomizdat, 1989. 528 p. (Rus)

9. Grebchenko N.V., Maximchuk V.F., Pilipenko J.V. Determination of the distance to the single-phase circuits on overhead lines. Tekhnichna Elektrodynamika. 2016. No 4. Pp. 83-85. (Ukr) 